\title{
Neurological disease or conversion disorder? Important aspects of differential diagnosis - psychiatric and psychotherapeutic perspective. Case report
}

\author{
Choroba neurologiczna czy zaburzenie konwersyjne? Ważne aspekty diagnozy różnicowej \\ -perspektywa psychiatryczna i psychoterapeutyczna. Opis przypadku
}

\section{Sara Tomczak ${ }^{1}$ ABDEFT, Hanna Gorejko ${ }^{1}$ ABDE, Wiktor Dróżdżं ${ }^{2}$ DEFT,}

${ }^{1}$ Ist Department of Psychiatry in Bydgoszcz, Collegium Medicum, Nicolaus Copernicus University in Toruń

${ }^{2}$ IInd Department of Psychiatry in Toruń, Collegium Medicum, Nicolaus Copernicus University in Toruń

\begin{abstract}
Introduction: Amyotrophic lateral sclerosis is a progressive neurodegenerative disease with undetermined etiology. Due to diverse symptomatology, it requires a thorough differential diagnosis, with consideration of conversion disorders. The presented thesis describes a case of a young man hospitalized in the Department of Psychiatry in order to verify the possible psychogenic basis of his symptoms, which previously were considered to be a manifestation of neurological disease with an unfavorable prognosis.

Aim: The aim of the thesis is to raise the issue of a multidisciplinary approach to diagnostic process in medicine, as well as taking into account the legitimacy of including psychiatrists, psychologists, and psychotherapists in diagnostic teams.

Case study: We present a case report of a man who has been experiencing progressive feeling and walking problems for the past several years, which originally suggested a neurological or rheumatological disease. Earlier observations and medical tests had led to a diagnosis of amyotrophic lateral sclerosis. After several years, the diagnosis was excluded, and the patient was referred to the Department of Psychiatry to determine the possible psychogenic basis of his symptoms. Diagnostic methods used during the patient's hospitalization confirmed the conversational nature of his symptoms, and both pharmacological and psychotherapeutic treatment caused reduction of severity of his symptoms and allowed him for a gradual return to independent functioning.

Conclusion: Analysis of the collected data, including patient's life history and a course of his treatment, indicates the validity of a holistic approach to medical problems, which implies the inclusion of specialists in the field of psychiatry, psychology, as well as psychotherapists in diagnostic teams. Such a multidimensional view of the patient and the source of his symptoms may allow for faster diagnosis and may also contribute to reducing the risk of making mistakes such as an incorrect assessment of factors triggering the disease process.
\end{abstract}

Keywords: conversion disorders, amyotrophic lateral sclerosis, differential diagnosis

\section{Streszczenie}

Wstęp: Stwardnienie zanikowe boczne to postępująca choroba neurodegeneracyjna o nieustalonej etiologii. Z uwagi na różnorodną symptomatologię wymaga ona wnikliwej diagnostyki różnicowej, w tym uwzględnienia zaburzeń konwersyjnych. W przedstawianej pracy opisano przypadek młodego mężczyzny hospitalizowanego w Klinice Psychiatrii w celu weryfikacji możliwego podłoża psychogennego objawów, które wcześniej zostały uznane za manifestację choroby neurologicznej o niepomyślnym rokowaniu.

Cel: Celem pracy jest poruszenie kwestii multidyscyplinarnego podejścia do procesu diagnostycznego w medycynie, w tym zwrócenie uwagi na zasadność włączania do zespołów diagnostycznych psychiatrów, psychologów i psychoterapeutów.

Opis przypadku: Prezentujemy opis przypadku mężczyzny, który od kilku lat doświadczał postępujących problemów z czuciem i chodzeniem, co pierwotnie sugerowało chorobę o podłożu neurologicznym lub reumatologicznym. Wcześniejsze obserwacje i badania doprowadziły do postawienia diagnozy stwardnienia zanikowego bocznego. Po kilku latach rozpoznanie to zostało wykluczone, a pacjent został skierowany do Kliniki Psychiatrii, by określić ewentualne psychogenne podłoże objawów. 
Zastosowane podczas hospitalizacji metody diagnostyczne potwierdziły konwersyjny charakter symptomów, a leczenie farmakologiczne oraz psychoterapeutyczne spowodowało zmniejszenie nasilenia objawów oraz pozwoliło na stopniowy powrót pacjenta do samodzielnego funkcjonowania.

Wnioski: Analiza zgromadzonych danych, w tym historii życia i przebiegu leczenia pacjenta, wskazują na zasadność holistycznego podejścia do problemów medycznych, co implikuje włączanie do zespołów diagnostycznych specjalistów w dziedzinie psychiatrii, psychologii, jak i psychoterapeutów. Takie wielowymiarowe spojrzenie na pacjenta i źródła jego objawów może pozwolić na szybsze postawienie rozpoznania oraz przyczynić się do zmniejszenia ryzyka popełnienia pomyłek, polegających na niewłaściwej ocenie czynników wyzwalających proces chorobowy.

Słowa kluczowe: zaburzenia konwersyjne, stwardnienie zanikowe boczne, diagnoza różnicowa

\section{Introduction}

Amyotrophic lateral sclerosis (Latin: sclerosis lateralis amyotrophica, SLA) is a disease entity known in medicine for nearly 150 years. Its first description was made in 1869 by the French physician Jean-Martin Charcot [1]. In reference to the name of the discoverer of the ALS, it is often interchangeably called Charcot's disease. This condition is a progressive neurodegenerative disease with an unidentified cause. The search for possible factors affecting the occurrence of ALS indicates, among others, genetic determinants [2]. There are also reports that point out more complex etiology of the disease and a significant possible impact of not only the mentioned genetic factors but also toxic factors as well as environmental conditions [3]. The essence of this disease is the damage of motor neurons, which causes progressive muscle paralysis, gait disturbances, and eventually also affects breathing. Consequently, because of respiratory muscles paralysis, it leads to the death of a sick person [4]. In substantial proportion of cases, the progressive disease process leads to death within two years (c.a. $20 \%$ of persons). Approximately half of the patients survive for five years, and extremely rarely, the disease takes on a chronic character and then the patient's life may last for a decade or longer [5].

The diagnosis of amyotrophic lateral sclerosis is largely based on the clinical assessment of symptoms, and before such a diagnosis is made, a reliable differential diagnosis should be made to exclude other disease entities that may be symptomatically similar [6]. During the differentiation process, a number of tests should be performed, such as cerebrospinal fluid examination, neuroimaging i.e. magnetic resonance, electrophysiological tests, and some serological tests. According to the available data, there are many syndromes or disease entities that can mimic the symptoms of ALS, so before making final diagnosis, other illnesses should be excluded [7].

The above-mentioned rule mainly focused on differential diagnosis in the neurological area, whereas an equally important aspect should have been psychiatric consultation in order to differentiate the underlying somatic symptoms from psychogenic disorders, for example from conversion disorder. It seems necessary because symptomatology of conversion disorders can mimic various somatic diseases, including those with a neurological background. There have been reported cases of individuals who, due to conversion, i.e. transformation of mental stress into somatic symptoms, developed symptoms of paralysis, which resolved only after adequate therapy and the patient's understanding of the sources of the disease [8].

Conversion and dissociative disorders, according to the diagnostic criteria of the International Classification of Mental Diseases ICD-10, take place when "partial or complete loss of proper integration between memories of the past, self-identity, direct impressions and control of whichever body movements" occur [9]. These disorders belong to the category of neurotic disorders, in ICD10 described in section "Neurotic, stress-related and somatoform disorders", including diagnoses from F40 to F48. Dissociative and conversion disorders are category F44 [10]. Depending on the form, the symptoms are coded with an additional number e.g. F44.4 - dissociative motor disorders. According to the DSM-5 classification guidelines, the nature of the disorder in terms of duration should be additionally determined, i.e. whether an acute or persistent episode is present and verify the existence of a definite, specific psychological factor causing the disorder or diagnose its absence [11].

Various "conversions" are described in the literature as possible consequences of facing a traumatic experience when mental tension is repressed from consciousness and moved to the subconsciousness [12]. While experiencing strong stress again, these contents may take control over human actions and cause the disruption of various functions, including disturbances in the memory, perception and even physical activity [13]. Symptoms may then imitate somatic and brain diseases, and this may generate difficulties and significantly prolong differential diagnosis, especially in the area of neurology [14].

In this case study, we present a case of a young man who reported to the doctor because of gait and sensation disorders. These symptoms, after months of testing, were classified as a manifestation of amyotrophic lateral 
sclerosis. The patient was diagnosed with this progressive neurological disease with an extremely unfavorable prognosis, living for the following months in the belief that he would most likely die in about two years. Due to the persistent symptoms, significant gait disorder and suffering associated with it, the patient sought help in various centers throughout the country. At some stage of further clinical observation, this diagnosis was undermined and the patient was referred for psychiatric observation to verify the possible psychosomatic basis of the symptoms.

\section{Case study}

The thirty-year-old man was admitted to the Department of Treatment of Anxiety and Affective Disorders of Psychiatry Clinic in Bydgoszcz in order to carry out a psychiatric and psychological diagnosis, due to his somatic complaints of unclear etiology that had been going on for at least three years. The main observed symptoms were joint and muscular pain, weakness in muscle strength, contractures in the joints of both hands and tetraparesis. These symptoms excluded the patient from performing his current professional duties and significantly hindered his daily functioning. During admission, the man also complained of frequent headaches, worrying about the future, mood variability, and irritability. He indicated the feeling of inner anger and even rage, while on the outside expressing apparent calmness. As he reported, he also periodically felt indifferent to everything and was experiencing despondency.

The patient's first symptoms started with pain of the right ankle joint. It was not preceded by an injury but was intensified during physical effort. This was followed by pain with swelling of the left ankle and both wrists. Due to the weakening of his muscle strength, the man began to drop objects from his hands and was experiencing problems with walking. Since then, he has been diagnosed orthopedically, rheumatologically and neurologically. During this period he was also hospitalized several times. During his stay at the rheumatology rehabilitation ward, after neurological consultation, he was transferred to the Neurology Clinic, where he was diagnosed with amyotrophic lateral sclerosis, bulbar type. After some time, however, this diagnosis was withdrawn. As a result, other considered diagnostic hypotheses have been rejected, including, but not limited to, possible connective tissue disease, Lyme disease, and bacterial infection Chlamydia or Yersinia. Diagnosis of myopathy has also started. However, the clinical picture and the EMG examination did not correspond to ALS diagnosis or other neuromuscular disorders. Due to the prevailing functional disorders (gait disturbances, muscle tremors, paresis), the severity of which decreased after the patient's attention was dispersed, he was referred for a psychiatric consultation, after which he was qualified for diagnosis in the Department of Psychiatry, with suspicion of conversion disorders.

\section{The course of psychiatric and psychotherapeutic diagnostics}

At the beginning of hospitalization, the subject underwent a series of psychological tests and participated in a diagnostic psychotherapeutic interview. An extensive, structured psychotherapeutic interview took several meetings and allowed to create a psychological profile of a subject and enabled to recognize the psychological defense mechanisms of the patient, and this, in turn, contributed to the understanding the possible psychosomatic source of his symptoms.

Based on the interview, it was established that the subject comes from a full family. He was the eldest of five siblings. He was brought up in a very small village. Born by spontaneous natural delivery, he obtained 10 points on the Apgar scale. The course of pregnancy and perinatal period was uncomplicated. Infant period was without deviations. The living and material conditions of his family during his childhood and adolescence were very difficult. The patient described the relationship with his mother as good at that time. As he mentioned, she was always a warm and very hard-working person, who took care of and provided for her family and home. The father, at that time, was mostly unemployed, he regularly abused alcohol, he used psychological and physical violence (both toward his wife and children). He dominated the family, and the patient has never had good contact with him.

The patient began his education in kindergarten at the age of six. As he described, he was then a withdrawn and lonely child. He was afraid of interacting with others, which is why, now, he connects that mostly with the fact that he was regularly experiencing violence at home. He did not have any friends until the fourth grade of primary school. His peers often teased him because of the low material status of his family of origin and his father's alcohol problem. During that time, the man was also experiencing considerable learning difficulties. In junior high school, he attended a class in which there were many people "with problems". Back then, he faced verbal and physical aggression regularly. He was also aggressive himself. Wanting to raise fear among peers and to feel safer, he started training boxing and going to the gym. With growing independence and maturation, the man began to perform better at school. In high school, he began to receive very good grades, and he felt accepted by others. However, as he said, he was always reserved and tried neither to show his emotions nor share his difficulties 
with others.

He took up his professional work right after high school. It was in line with his earlier plans and aspirations. At the start, he felt right and he was promoted several times. After the last change in the position, his responsibilities increased significantly, he also got a lot of new duties and his co-workers (especially those who were higher in the company's structures) did not respect him. The patient was given numerous tasks beyond his post. He also regularly had to bear consequences for the mistakes that were not his or for the decisions he felt forced to make. As he claims, he could not oppose. He did not talk to anyone about his experiences, he tried not to show any emotions related to it. On the outside, he showed that everything was fine because he really wanted this particular job. He wanted, unlike his father, to provide constant support for his family. In addition, the profession he performed allowed him to feel strong and masculine. Simultaneously with the increasing difficulties at work, one of the patient's brothers was diagnosed with cancer, and after a relatively short time died. The patient kept his dying brother company in the last moments of his life. He did not show his sadness at that time, he did not allow himself for any emotions during the period of mourning. As he said, he wanted to be as strong as his brother, who was cheerful and encouraging for his family before his death.

About three years before the described hospitalization, the patient's health problems had begun. Initially, he did not undertake certain duties at work. However, over time, due to the intensification of patient's pain symptoms and progressive paresis, the process of excluding him from subsequent professional duties was also progressing and the man was often on sick leave. For about a year and a half, he was seen by orthopaedists and physiotherapists. Due to the lack of improvement, he was referred for a diagnostic stay to the rheumatic rehabilitation department, and then transferred to the Neurology Clinic. At that time he was diagnosed with amyotrophic lateral sclerosis (ALS) and was informed that he had approximately two years of life left. Initially, the patient was completely unable to cope with the emotions that appeared in response to the diagnosis. These circumstances generated suicidal thoughts with plans, but the patient did not attempt suicide.

During this period, the man was in a relationship with his partner, and shortly before hospitalization at the Department of Psychiatry, they got married. The symptoms were progressing, and the patient at his wedding had to use the wheelchair because he was no longer able to move independently. In general, he assessed the relations with his wife as "very good". According to his story, it was true partnership, they supported and talked to each other a lot, although, what the patient noticed, it was usually his wife who was talking while he was listening. The couple brought up a child together, who at the time of psychiatric hospitalization was about one year old.

As a result of the ALS diagnosis, the patient lost his job and received a disability allowance. After several months and family persuasion, he decided on another hospitalization to verify the established diagnosis. As described above, ALS was excluded at that time and other somatic diseases, including various neurological units, were gradually being eliminated as well. Because gait disturbances, muscle tremors, and other functional disorders were progressing, the patient was finally referred for a psychiatric treatment.

\section{Psychotherapeutic understanding of symptoms}

Data obtained during the interview, clinical observation of the patient during the stay, together with the exclusion of the somatic background of his symptoms and the conscious symptom simulation, were the basis for the diagnosis of the conversion disorder. The predisposing factor to the disorder's occurrence was primarily the patient's relationship with his father, in which the man was experiencing physical and psychological violence. He was a victim in it, and because of the obvious dependence, the patient had no other possibility of functioning than in subordination. As a consequence, an internal object, a punishing father, was formed who "did not allow" the patient to show emotions in difficult situations. Only such functioning was not associated with weakness, the man perceived it as masculine, correlated with the strength he valued. Increasing difficulties at work, the need to subordinate, ridiculing by colleagues as well as illness and death of his brother, caused the patient to have numerous emotions, such as sadness, fear, anger, with which he could not cope alone. All of these circumstances triggered the symptoms. Unexpressed and suppressed feelings gradually grew, revealing themselves in somatic ailments. Through symptoms, the man was achieving a secondary benefit mainly in the form of avoiding difficult situations at work. In turn, the concentration on somatic complaints he was experiencing and which were diagnosed as progressive, fatal disease, deepened anxiety and emotional symptoms, thus creating a vicious circle mechanism that would aggravate the symptoms.

\section{The therapies and their effects}

During the hospitalization, pharmacological treatment was used (at the discharge: escitalopram 15 $\mathrm{mg}$ /day and mianserin hydrochloride $10 \mathrm{mg}$ overnight). Due to the conversive nature of the symptoms, the patient also took part in psychotherapy: initially individual and 
later also group therapy. The main goal of the therapeutic work was to increase the patient's awareness of the impact of his emotional states on various body experiences and to increase his contact with his own feelings and competence in their expression. At the same time, the man had the opportunity to examine the influence of experiences from the history of his life on the current functioning. The above-mentioned actions were aimed primarily at eliminating the unconscious internal conflict between the desire to express difficult emotions, being in genuine contact with oneself, and the fear of experiencing oneself as weak and unmanly and being misunderstood and rejected. As a consequence of the actions taken, the man's health improved, what was observed both in motor and in mental functioning.

In terms of motor capabilities, the patient's gait quality improved - the patient was moving on his own, and the gait itself was much more reliable and stable than at the beginning of hospitalization, although he was still slowed down. The paresis in the hands also decreased, the patient could press a door handle again, grasp lighter items (without dropping) and manipulate them. The partial recovery in motor functioning allowed the man to return to his daily duties, including independent care of his own child, which was previously impossible.

Improvement of psychological well-being was also observed. The patient's mood was evened out, and the patient himself declared that he felt clearly calmer. However, occasionally, he was still worried about his family and his own future. Only partial improvement in both psychological and somatic symptoms resulted most probably from deeply rooted sources of the patient's experience of difficulties and were associated with his personal tendencies to deal abnormally with reality and encountered problems.

Despite the profound nature of experienced symptoms and the fact that these symptoms did not completely disappear, the improvement was satisfactory enough that the patient was discharged from the hospital on the scheduled date in a stable mental state. There was no need for further treatment on stationary basis, however, in order to maintain current progress and further therapeutic work in the sources of symptoms area, it was recommended that the patient would continue psychotherapy and psychiatric treatment in outpatient settings.

\section{Discussion}

The described case shows the complexity and importance of a properly conducted differential diagnosis in musculoskeletal disorders. Its key task is to determine whether it is due to organic or psychogenic causes. The crucial component of this process, in the first order, is to exclude the somatic basis of symptoms. The exact evaluation of physical condition, including neurological, is a necessary condition in order to avoid disastrous errors [15]. When lack of organic causes of disorders is confirmed, it is recommended to start searches of possible non-somatic sources of symptoms.

The significance of a thorough differentiation between somatic and psychogenic basis and the necessity of cooperation between neurologists and psychiatrists is also highlighted by other researchers. In addition, they place emphasis on the fact that psychogenic disorders apply to about $3.5 \%$ patients diagnosed neurologically, although almost $10 \%$ of them can experience coexisting symptoms of the organic basis [16]. Downplaying this fact and a hasty diagnosis of an exclusively psychosomatic nature of symptoms can result in misdiagnosis of another pathological process affecting a patient. Such diagnostic error, delaying proper treatment of somatic disease, can take a serious toll on one's health, and in some cases it can even lead to patient's death.

A different neglect, which can also negatively affect patient outcomes, is missing the psychogenic basis of symptoms. It similarly delays the introduction of proper treatment, both pharmacological and psychotherapeutic.

In both cases, due to misdiagnosis, no adequate therapeutic actions are applied, what can lead to secondary, negative consequences on patients' health, and the entire treatment process. First of all, suffering experiences persisted over an extended period of time in patient, leading sometimes to symptoms of secondary trauma. It happened during the described case, when a man, due to misdiagnosis of a deadly neurological disorder, followed by an extended therapy of psychogenic diseases, suffered psychic trauma. As a result, he lost confidence in his medical team and his cooperation with medical staff was deteriorating.

Other writers also mentioned similar issues; in their studies, they described persons with symptoms classified first as somatic disorders, and after psychiatric and psychological evaluation, their psychogenic basis was confirmed. One of these works describes a case of a young man who was initially diagnosed with epilepsy, and during differential diagnosis it was determined that the symptoms are psychosomatic in nature. After completion of interdisciplinary diagnostic process, including neurological, psychiatric and psychological examination, the patient was diagnosed with mixed dissociative disorders with histrionic personality disorder traits [17].

Another publication emphasized that in order to ensure effective cooperation between psychologists, psychiatrists and other specialty physicians, certain conditions have to be met. Researchers describe in it what should be the main focus during inclusion of mental health 
specialists to the diagnostic process in patients with functional musculoskeletal disorders [18].

Summarizing, the results of observation conducted by us, as well as conclusions coming from works of other authors, indicate the appropriateness of the multidisciplinary approach to the differential diagnosis. The list of results and conclusions underlines the need of inclusion of psychiatrists, psychologists and psychotherapists to diagnostic teams. Their role can go beyond providing support to patients facing a diagnosis of a serious disease - their additional task should be diagnosing possible non-somatic causes of clinical problems. Such cooperation proves to be helpful for proper verification of the causes of disorders, allowing also to accelerate this process.

\section{Conclusion}

In the described case study, the diagnostic process initially led to the diagnosis of amyotrophic lateralsclerosis in the examined man. However, no differential diagnosis was made towards the possible psychosomatic background of the disorder. Only further proceedings with the use of psychological, psychiatric and clinical observation methods led to the diagnosis of conversion disorders. The described case indicates that making the initial psychiatric and psychological consultation as late as three years after the onset of neurological symptoms is an omission that is difficult to justify. It is worth pointing out that even if there is no doubt about the somatic nature of the symptoms, the occurrence of a clear emotional response to the diagnosis of a serious illness is an indication for the consultation by a psychiatrist or psychologist. The prolonging diagnostic process - without the participation of mental health specialists - has adversely affected the psychological state of the subject and the entire further process of his treatment. Patient's mood deterioration and significant increase in distrust of the medical staff and reluctance to treat was observed. This resulted in poorer co-operation in the therapeutic process, which ultimately had negative effect on achieving symptomatic improvement and significantly delayed the recovery of the patient's abilities. A very important aspect is also the fact that due to the diagnosis of a deadly neurological disease, in spite of the lack of it, the patient has experienced psychological trauma.

Applied pharmacological treatment of escitalopram and mianserin was justified by the presence of pronounced symptoms of depression. Whereas, the data on the effectiveness of such treatment in relation to conversion symptoms is scarce. It indicates the possibility of a beneficial effect of SSRIs on the alleviation of the severity of chronically occurring conversion motor symptoms [19]. Data from clinical trials suggest the need for treating individuals with the motoric type of conversion disorders with combined pharmacological and psychotherapeutic treatment [20, 21]. Such therapeutic interventions were undertaken in the presented case and brought a clear reduction in the severity of both conversion and depressive symptoms.

The described case indicates the need for a multidisciplinary approach to differential diagnosis and draws attention to the necessity of including both psychiatrists and psychologists in diagnostic teams. Their role may go beyond providing support to patients in the face of a diagnosis of serious disease and their additional task might be searching for non-somatic causes of clinical problems. Such cooperation and interdisciplinary differential diagnosis may be helpful not only to verify the causes of disorders, but also may positively hasten establishing the correct diagnosis, reducing the psychological burden associated with a prolonged diagnostic process and, on the other hand, positively influence the patient's mental state.

\section{Wstęp}

Stwardnienie zanikowe boczne (łac. sclerosis lateralis amyotrophica, SLA) to jednostka chorobowa znana w medycynie od blisko 150 lat. Pierwszego jej opisu dokonał w 1869 roku francuski lekarz Jean-Martin Charcot [1]. W nawiązaniu do nazwiska odkrywcy SLA jest często zamiennie nazywane chorobą Charcota. Schorzenie to jest postępującą chorobą neurodegeneracyjną o nieustalonej jednoznacznie przyczynie. Poszukiwania możliwych czynników wpływających na wystąpienie SLA wskazują między innymi na jego genetyczne uwarunkowania [2]. Istnieją również doniesienia, które wskazują na bardziej złożoną etiologię choroby i istotny możliwy wpływ nie tylko wspomnianych czynników genetycznych, ale również czynników toksycznych, jak i uwarunkowań środowiskowych [3]. Istotą tego schorzenia jest porażenie neuronów ruchowych, co powoduje postępujący paraliż mięśni, zaburzenia chodu, a ostatecznie również oddychania, ponieważ porażenie obejmuje mięśnie oddechowe- w konsekwencji prowadzi to do śmierci osoby chorej [4]. W większości przypadków postępujący proces chorobowy doprowadza do zgonu w ciągu dwóch lat (u około $20 \%$ chorych). Mniej więcej połowa chorych przeżywa do pięciu lat, a niezwykle rzadko choroba przybiera charakter przewlekły i wówczas życie pacjenta może trwać dekadę lub dłużej [5].

Rozpoznanie stwardnienia zanikowego bocznego w znacznej mierze opiera się na ocenie klinicznej objawów, a przed postawieniem takiego rozpoznania 
należy dokonać rzetelnej diagnozy różnicowej, by wykluczyć inne jednostki chorobowe, które mogą objawowo je przypominać [6]. W procesie różnicowania należy wykonać szereg badań, takich jak badanie płynu mózgowo-rdzeniowego, badanie neuroobrazowe pod postacią rezonansu magnetycznego, badania elektrofizjologiczne oraz niektóre badania serologiczne. Jak wynika z dostępnych danych istnieje wiele zespołów czy jednostek chorobowych, które mogą imitować objawy SLA, zatem przed ostatecznym postawieniem takiego rozpoznania należy wykluczyć wszystkie z nich [7].

Przywołane wyżej prace w znacznej mierze skupiały swoją uwagę na diagnostyce różnicowej w obszarze neurologicznym, natomiast równie istotnym aspektem powinno być poszerzenie postępowania o konsultację psychiatryczną w celu zróżnicowania objawów o podłożu somatycznym od zaburzeń psychogennych, na przykład od zaburzeń konwersyjnych. Wydaje się to konieczne ponieważ $\mathrm{w}$ swej symptomatologii zaburzenia konwersyjne mogą naśladować różne choroby somatyczne, w tym te o podłożu neurologicznym. Opisywane były przypadki osób, u których na skutek konwersji, czyli przekształcenia stresu psychicznego w objawy somatyczne, pojawiły się objawy paraliżu, które ustąpiły dopiero po przejściu adekwatnej terapii oraz zrozumieniu przez pacjenta źródeł choroby [8].

Do zaburzeń konwersyjnych oraz dysocjacyjnych, zgodnie z kryteriami diagnostycznymi Międzynarodowej Klasyfikacji Chorób i Zaburzeń Psychicznych ICD10, dochodzi w momencie gdy wystąpi „częściowa lub całkowita utrata prawidłowej integracji między wspomnieniami przeszłości, poczuciem własnej tożsamości, bezpośrednimi wrażeniami i kontrolą dowolnych ruchów ciała" [9]. Zaburzenia te należą do kategorii zaburzeń nerwicowych, w ICD-10 opisywanych w dziale Zaburzenia nerwicowe, zaburzenia związane ze stresem i pod postacią somatyczną, obejmując rozpoznania od F40 do F48. Zaburzenia dysocjacyjne i konwersyjne to kategoria F44 [10] . W zależności od postaci, objawy są kodowane dodatkowym znakiem np. F44.4 - dysocjacyjne zaburzenia ruchu. Zgodnie z wytycznymi klasyfikacji DSM-5 należy dodatkowo określić charakter zaburzeń pod względem czasu trwania czyli ocenić, czy mamy do czynienia z epizodem ostrym czy uporczywym oraz zweryfikować istnienie uchwytnego, konkretnego stresowego czynnika psychologicznego wywołującego zaburzenie lub też zdiagnozować jego brak [11].

W literaturze opisywane są różne „konwersje”, gdzie po doświadczeniu traumatycznego przeżycia, jego treść zostaje odcięta od świadomości i wyparta do podświadomości [12]. Przy ponownym przeżyciu silnego stresu treści te mogą przejąć kontrolę nad działaniem człowieka i wpływać na zaburzenia różnych funkcji, w tym prowadzić do zakłóceń w sferze pamięci, postrzegania zmysłowego, a nawet aktywności ruchowej [13]. Objawy mogą wówczas imitować choroby somatyczne i neurologiczne, co znacząco przedłuża i utrudnia prowadzenie różnicowania w obszarze przyczyn pojawienia się objawów oraz postawienie właściwego rozpoznania [14].

W niniejszej pracy kazuistycznej przedstawiamy przypadek młodego mężczyzny, który zgłosił się do lekarza z powodu zaburzeń chodu i czucia. Objawy te, po miesiącach badań, zostały zakwalifikowane jako manifestacja stwardnienia zanikowego bocznego. Pacjent otrzymał rozpoznanie tej postępującej neurologicznej choroby o skrajnie niepomyślnym rokowaniu, żyjąc przez kolejne miesiące w przekonaniu, że najprawdopodobniej umrze w ciągu około dwóch lat. Z uwagi na utrzymujące się objawy, znaczne zaburzenia chodu oraz cierpienie z tym związane, pacjent poszukiwał pomocy w różnych ośrodkach na terenie całego kraju. Na pewnym etapie dalszej obserwacji klinicznej diagnoza ta została podważona, a pacjent został skierowany na obserwację psychiatryczną, by zweryfikować możliwe psychosomatyczne podłoże symptomów.

\section{Opis przypadku}

Trzydziestoletni mężczyzna został przyjęty do Oddziału Leczenia Zaburzeń Lękowych i Afektywnych Kliniki Psychiatrii w Bydgoszczy, celem wykonania diagnozy psychiatrycznej i psychologicznej, w związku z utrzymującymi się już co najmniej od trzech lat licznymi dolegliwościami somatycznymi o nieustalonej etiologii. Główne obserwowane objawy to bóle stawowo - mięśniowe, osłabienie siły mięśniowej, przykurcze w stawach obu dłoni oraz tetrapareza. Dolegliwości te wyłączyły pacjenta z wykonywania dotychczasowych obowiązków zawodowych i znacznie utrudniały mu codzienne funkcjonowanie. Przy przyjęciu mężczyzna skarżył się także na częste bóle głowy, zamartwianie się o przyszłość, zmienność nastroju oraz drażliwość. Wskazywał na uczucie wewnętrznej złości a nawet wściekłości, z jednocześnie obserwowanym pozornym spokojem na zewnątrz. Jak podawał, okresowo odczuwał też obojętność na wszystko i przygnębienie.

Pierwsze objawy u pacjenta zaczęły się od bólu prawego stawu skokowego. Nie został on poprzedzony żadnym urazem, natomiast nasilał się podczas wysiłku fizycznego. Następnie pojawił się ból z obrzękiem stawu skokowego lewego oraz obu nadgarstków. Z powodu osłabienia siły mięśniowej mężczyźnie zaczęły wypadać przedmioty $\mathrm{z}$ rąk, doświadczał problemów z chodzeniem. Od tamtego czasu był on diagnozowany zarówno ortopedycznie, reumatologicznie, 
jak i neurologicznie. W tym okresie był w również kilkukrotnie hospitalizowany. W trakcie pobytu w oddziale rehabilitacji reumatologicznej, po konsultacji neurologicznej, przeniesiono go do Kliniki Neurologii, gdzie postawiono rozpoznanie stwardnienia zanikowego bocznego, odmiana opuszkowa. Po pewnym czasie anulowano jednak tę diagnozę. Kolejno odrzucano także hipotezy o innych schorzeniach m.in. o możliwej chorobie tkanki łącznej, boreliozie, zakażeniu bakteryjnym Chlamydia lub Yersinia. Rozpoczęto również diagnostykę w kierunku miopatii. Obraz kliniczny oraz badanie EMG nie odpowiadały jednak także i temu rozpoznaniu, ani innym schorzeniom z kręgu nerwowo - mięśniowych. W związku z dominującymi zaburzeniami funkcjonalnymi (zaburzenia chodu, drżenia mięśni, niedowład), których nasilenie zmniejszało się po rozproszeniu uwagi pacjenta, skierowano go na konsultację psychiatryczną, po której został zakwalifikowany do diagnostyki w Klinice Psychiatrii, z podejrzeniem zaburzeń konwersyjnych.

\section{Przebieg diagnostyki psychiatrycznej i psychoterapeutycznej}

Badany na początku hospitalizacji wykonał baterię testów psychologicznych oraz uczestniczył $\mathrm{w}$ diagnostycznym wywiadzie psychoterapeutycznym. Obszerny, trwający kilka spotkań, ustrukturalizowany wywiad psychoterapeutyczny pozwala na stworzenie psychologicznego profilu badanego oraz umożliwia poznanie mechanizmów obronnych, występujących u osoby badanej, co w konsekwencji przyczynia się do zrozumienia ewentualnego psychosomatycznego źródła jej objawów.

Na podstawie wywiadu ustalono, że badany pochodzi z rodziny pełnej. Był najstarszym z pięciorga rodzeństwa. Wychowywał się w bardzo małej wsi. Urodzony siłami natury, uzyskał 10 punktów w skali Apgar. Przebieg ciąży i okres okołoporodowy niepowikłane. Okres niemowlęcy bez odchyleń. Warunki bytowe i materialne jego rodziny w okresie dzieciństwa i dorastania były bardzo trudne. Relacje z matką z tamtego czasu pacjent określał jako dobre. Jak wspominał, zawsze była ona osobą ciepłą i bardzo pracowitą, dbała o rodzinę i zajmowała się utrzymaniem domu. Ojciec $\mathrm{w}$ tamtym okresie był najczęściej bezrobotny, regularnie nadużywał alkoholu, stosował przemoc psychiczną i fizyczną (zarówno wobec żony, jak i dzieci). To on dominował w rodzinie, a pacjent nigdy nie miał z nim dobrego kontaktu.

Edukację mężczyzna rozpoczął w szóstym roku życia od zerówki. Jak określał, był wtedy dzieckiem wycofanym i samotnym. Obawiał się interakcji z innymi, co łączy obecnie głównie z tym, że w domu był regularnie przemocowo traktowany. Aż do 4 klasy szkoły podstawowej nie miał kolegów. Rówieśnicy często dokuczali mu ze względu na niski status materialny jego rodziny pochodzenia oraz problem alkoholowy ojca. Mężczyzna doświadczał w tamtym okresie znacznych trudności w nauce. W szkole gimnazjalnej uczęszczał do klasy, w której było wiele osób „z problemami”. Spotykał się wtedy regularnie z agresją słowną oraz fizyczną. Sam także bywał agresywny. Chcąc wzbudzać wśród rówieśników strach oraz by czuć się bezpieczniej zaczął trenować boks i chodzić na siłownię. Wraz ze wzrastającą samodzielnością i dojrzewaniem mężczyzna zaczynał coraz lepiej radzić sobie $w$ szkole. W liceum zaczął otrzymywać bardzo dobre wyniki w nauce, a także czuł się akceptowany przez innych. Jak mówił, zawsze jednak był skryty, starał się nie okazywać uczuć ani nie dzielił się swoimi trudnościami z innymi.

Pracę zawodową pacjent podjął zaraz po szkole średniej. Była ona zgodna z jego wcześniejszymi planami i aspiracjami. Początkowo czuł się w niej dobrze, kilkakrotnie awansował. Po ostatniej zmianie stanowiska znacznie wzrósł zakres jego odpowiedzialność, dostał również dużo nowych obowiązków, a współpracownicy (zwłaszcza ci postawieni wyżej w strukturach zakładu pracy) nie szanowali go. Pacjent otrzymywał do wykonania liczne zadania leżące poza jego kompetencjami lub poza jego odpowiedzialnością. Regularnie zaczął też ponosić konsekwencje za nie swoje błędy lub za decyzje, do których podejmowania czuł się zmuszany. Jak twierdzi - nie miał możliwości przeciwstawiania się. Z nikim nie rozmawiał o swoich doświadczeniach, starał się zupełnie nie okazywać związanych z tym emocji. Na zewnątrz pokazywał, że wszystko jest w porządku, bo bardzo zależało mu na tej konkretnej pracy. Chciał - w odróżnieniu od ojca - zapewniać stałe utrzymanie swojej rodziny. Ponadto zawód, który wykonywał, pozwalał mu na czucie się silnym i męskim. Równolegle z nasilającymi się trudnościami w pracy, jeden z braci pacjenta zachorował na nowotwór, a po stosunkowo krótkim czasie zmarł. Pacjent dotrzymywał umierającemu towarzystwa w ostatnich chwilach jego życia. Nie okazywał wówczas swojego smutku, nie dopuszczał emocji także w okresie żałoby. Jak mówił, chciał być tak silnym jak jego brat, który przed śmiercią był pogodny i podtrzymywał rodzinę na duchu.

Około trzy lata przed opisywaną hospitalizacją zaczęły się problemy zdrowotne pacjenta. Początkowo nie podejmował on jedynie niektórych obowiązków w pracy. Z czasem jednak, w związku z nasilaniem się dolegliwości bólowych oraz postępującym niedowładem, postępował także proces jego wykluczania z kolejnych obowiązków zawodowych, mężczyzna często przebywał na zwolnieniach lekarskich. Przez około półtora roku leczył się u ortopedów i fizjoterapeutów. Ze względu na brak poprawy został skierowany na pobyt 
diagnostyczny do oddziału rehabilitacji reumatologicznej, a potem przeniesiony do Kliniki Neurologii. Wówczas rozpoznano u niego stwardnienie zanikowe boczne (SLA) i poinformowano, że zostały mu mniej więcej dwa lata życia. Początkowo pacjent zupełnie nie mógł poradzić sobie z emocjami, które pojawiły się u niego w reakcji na powyższą diagnozę. Okoliczności te wywoływały u niego myśli suicydalne z planami - ostatecznie pacjent próby samobójczej nie podjął.

W tym okresie mężczyzna był w związku ze swoją partnerką, a krótko przed hospitalizacją w Klinice Psychiatrii wstąpili w związek małżeński. Objawy postępowały, a pacjent na własnym ślubie musiał korzystać z wózka inwalidzkiego, bo nie był już w stanie samodzielnie się poruszać. Relacje z żoną ogólnie oceniał bardzo dobrze. Zgodnie z jego opowieścią, ich związek oparty był na partnerstwie, wspierali się, dużo rozmawiali choć, co pacjent zauważał, to zazwyczaj żona mówiła podczas gdy on słuchał. Para wspólnie wychowywała dziecko, które w czasie opisywanej hospitalizacji psychiatrycznej miało około roku.

W związku ze zdiagnozowaną chorobą (SLA) badany utracił pracę i otrzymał rentę inwalidzką. Po kilku miesiącach, po namowach rodziny, zdecydował się na kolejną hospitalizację by zweryfikować otrzymane rozpoznanie. Tak jak opisano powyżej, anulowano wówczas diagnozę SLA oraz stopniowo wykluczano inne schorzenia somatyczne, w tym różne jednostki neurologiczne. Ponieważ zaburzenia chodu, drżenie mięśni i inne zaburzenia o charakterze funkcjonalnym postępowały, pacjent został ostatecznie skierowany na leczenie psychiatryczne.

\section{Rozumienie psychoterapeutyczne objawów}

Dane uzyskane podczas wywiadu, obserwacja kliniczna pacjenta podczas pobytu, wraz z wykluczeniem somatycznego podłoża jego dolegliwości jak i świadomej symulacji symptomów, stały się podstawą do rozpoznania u pacjenta zaburzeń konwersyjnych. Czynnikiem predysponującym do ich wystąpienia była przede wszystkim relacja pacjenta z jego ojcem, w której to mężczyzna doświadczał przemocy fizycznej i psychicznej. Był on w niej ofiarą, a ze względu na oczywistą zależność pacjent nie miał innej możliwości funkcjonowania niż w podporządkowaniu. W konsekwencji ukształtował się w nim wewnętrzny obiekt - karzący ojciec - który „nie pozwalał" pacjentowi na okazywanie emocji w sytuacjach trudnych. Tylko takie funkcjonowanie nie kojarzyło się mężczyźnie ze słabością, postrzegał je jako męskie, związane z cenioną przez niego siłą. Nasilające się trudności w pracy, konieczność podporządkowywania się, ośmieszanie przez współpracowników oraz choroba i śmierć brata, wywoływały u pacjenta liczne emocje, takie jak smutek, lęk, złość, z którymi nie mógł sobie sam poradzić

Wszystkie te okoliczności stanowiły czynniki wyzwalające objawy. Niewyrażane i tłumione uczucia stopniowo narastały, ujawniając się $\mathrm{w}$ dolegliwościach o charakterze somatycznym. Poprzez objawy mężczyzna osiągał wtórną korzyść głównie w postaci unikania trudnych dla niego sytuacji w pracy. Z kolei koncentracja na dolegliwościach somatycznych, których doznawał i które diagnozowane były jako postępująca, śmiertelna choroba, pogłębiały lęk i zaburzenia w obszarze emocjonalnym, tworząc tym samym mechanizm błędnego koła, zwrotnie nasilającego objawy.

\section{Zastosowane leczenie i jego efekty}

W trakcie hospitalizacji zastosowano u pacjenta leczenie farmakologiczne (przy wypisie: escitalopram $15 \mathrm{mg} / \mathrm{dz} \mathrm{mg}$ na dzień oraz mianseryna $10 \mathrm{mg}$ na noc). Z uwagi na konwersyjny charakter objawów badany brał także udział w psychoterapii: początkowo indywidualnej, a następnie grupowej. Głównym celem pracy terapeutycznej było zwiększenie świadomości pacjenta w zakresie wpływu jego stanów emocjonalnych na różne doświadczenia w ciele oraz zwiększenie jego kontaktu z własnymi uczuciami i zwiększenie kompetencji w ich ekspresji. Mężczyzna miał przy tym okazję przyjrzeć się wpływowi doświadczeń z historii jego życia na aktualne funkcjonowanie. Powyższe oddziaływania zmierzały przede wszystkim do eliminacji nieświadomego konfliktu wewnętrznego pomiędzy pragnieniem wyrażenia trudnych emocji, bycia w autentycznym kontakcie ze sobą, a obawą przed doświadczeniem siebie jako słabego i niemęskiego oraz przed byciem niezrozumianym i odrzuconym. W konsekwencji podjętych działań uzyskano poprawę stanu zdrowia mężczyzny, którą zaobserwowano zarówno w zakresie sprawności motorycznej, jak i w sferze funkcjonowania psychicznego.

W kwestii motorycznej zaobserwowano polepszenie jakości chodu pacjenta - pacjent poruszał się samodzielnie, a sam chód był dużo pewniejszy i stabilniejszy niż na początku hospitalizacji, choć nadal był spowolniony. Zmniejszył się również niedowład w dłoniach - pacjent mógł ponownie naciskać na klamkę, chwytać (bez upuszczania) lżejsze przedmioty oraz manipulować nimi. Wzrost sprawności pozwolił mężczyźnie na powrót co codziennych obowiązków, w tym także na samodzielne zajmowanie się dzieckiem, co wcześniej było zupełnie niemożliwe.

Obserwowano poprawę również w zakresie samopoczucia psychicznego. Nastrój pacjenta uległ wyrównaniu, a sam pacjent deklarował, że czuje się wyraźnie spokojniejszy. Mimo to nadal okresowo zamartwiał się o przyszłość swoją i swojej rodziny. 
Uzyskanie tylko częściowej poprawy w zakresie objawów psychologicznych, jak i będących ich następstwem objawów somatycznych, wynikało najprawdopodobniej z głęboko zakorzenionych źródeł doświadczanych przez pacjenta trudności oraz związanych z tym jego osobowościowych, nieprawidłowych tendencji do przeżywania rzeczywistości i napotykanych problemów.

Mimo głębokiego charakteru doświadczanych symptomów oraz faktu, iż objawy te nie ustąpiły całkowicie to uzyskana poprawa była na tyle zadowalająca, że pacjent został wypisany ze szpitala w zaplanowanym terminie, w stabilnym stanie psychicznym. Nie było wtedy konieczności dalszego leczenia $\mathrm{w}$ warunkach stacjonarnych, niemniej jednak w celu utrzymania dotychczasowych postępów oraz dalszej pracy terapeutycznej w obszarze źródeł objawów zalecono, by pacjent kontynuował psychoterapię i leczenie psychiatryczne w warunkach ambulatoryjnych.

\section{Dyskusja}

Opisany przypadek pokazuje jak złożonym i ważnym zadaniem jest prawidłowo przeprowadzona diagnoza różnicowa w zaburzeniach układu ruchu. Kluczowym jej zadaniem jest ustalenie, czy mamy do czynienia z przyczynami organicznymi czy psychogennymi. Zasadniczym elementem w tym procesie jest, w pierwszej kolejności, wykluczenie somatycznego podłoża symptomów. Dokładna ocena stanu fizycznego, w tym neurologicznego, jest warunkiem koniecznym aby nie dopuścić do fatalnych w skutkach pomyłek [15]. W sytuacji stwierdzenia braku organicznych przyczyn zaburzeń zaleca się rozpoczęcie poszukiwań możliwych pozasomatycznych źródeł objawów.

Wagę wnikliwego różnicowania podłoża somatycznego od psychogennego oraz konieczność współpracy pomiędzy neurologami i psychiatrami podkreślają także inni badacze. Zwracają oni ponadto uwagę na fakt, iż psychogenne zaburzenia ruchu dotyczą około 3,5 \% pacjentów diagnozowanych neurologicznie, choć blisko $10 \%$ z nich może doświadczać współistniejących objawów o podłożu organicznym [16]. Zbagatelizowanie tego faktu i zbyt pochopna diagnoza wyłącznie psychosomatycznego charakteru objawów może skutkować nierozpoznaniem toczącego się u pacjenta innego procesu chorobowego. Taka pomyłka diagnostyczna, opóźniając właściwą terapię choroby somatycznej, może doprowadzić do poważnego uszczerbku na zdrowiu, a w niektórych przypadkach nawet do śmierci pacjenta.

Odwrotnym zaniechaniem, które również skutkuje negatywnymi konsekwencjami dla pacjenta, jest pominięcie psychogennego podłoża objawów. Analogicznie opóźnia to włączenie odpowiedniego leczenia zarówno farmakologicznego, jak i psychoterapeutycznego.

W obu sytuacjach, wskutek nietrafnego rozpoznania, nie stosuje się adekwatnych oddziaływań terapeutycznych, co z kolei wywołuje wtórne, negatywne konsekwencje dla samego pacjenta, jak i całego procesu jego leczenia. Przede wszystkim wydłuża się czas cierpienia chorego oraz może dojść do wystąpienia u niego symptomów wtórnej traumatyzacji. Do takiej sytuacji doszło również w opisywanym przez nas przypadku, gdzie mężczyzna na skutek najpierw nietrafnego rozpoznania śmiertnelnej choroby neurologicznej, a następnie przedłużającej się terapii zaburzeń psychogennych, doznał traumy psychicznej. W efekcie obniżył się u niego poziomu zaufania do zespołu leczącego oraz pogorszyła się jakość jego współpracy z personelem.

$\mathrm{Na}$ podobne kwestie zwrócili uwagę również inni autorzy, którzy w swoich pracach opisywali osoby $\mathrm{z}$ objawami klasyfikowanymi wstępnie jako zaburzenia somatyczne, a po badaniu psychiatrycznym i psychologicznym stwierdzono ich psychogenne podłoże. $\mathrm{W}$ jednej $\mathrm{z}$ tych prac opisano przypadek młodego mężczyzny, u którego początkowo rozpoznano padaczkę, a $\mathrm{w}$ procesie różnicowania ustalono, iż obserwowane objawy mają charakter psychosomatyczny. Po zakończonym interdyscyplinarnym procesie diagnostycznym, obejmującym między innymi badanie neurologiczne, psychiatryczne i psychologiczne pacjent otrzymał ostatecznie rozpoznanie mieszanych zaburzeń dysocjacyjnych z cechami osobowości histrionicznej [17].

W innej publikacji podkreślano, że aby współpraca między psychologami, psychiatrami i lekarzami z innych dziedzin medycyny była efektywna, to powinny zostać spełnione określone warunki. Badacze opisują w niej na co zwracać szczególną uwagę przy procesie włączania specjalistów od zdrowia psychicznego do procesu diagnostycznego u pacjentów z czynnościowymi zaburzeniami ruchu [18].

Podsumowując, wyniki prowadzonych przez nas obserwacji, jak i wnioski płynące $\mathrm{z}$ przytoczonych prac innych autorów, wskazują na zasadność multidyscyplinarnego podejścia do diagnozy różnicowej. Zestawienie wyników i wniosków uwidacznia potrzebę włączania do zespołów diagnostycznych zarówno psychiatrów, psychologów, jak i psychoterapeutów. Ich rola może wykraczać poza udzielanie wsparcia pacjentom $\mathrm{w}$ obliczu rozpoznania u nich poważnej choroby - dodatkowym ich zadaniem powinno być diagnozowanie możliwych pozasomatycznych przyczyn problemów klinicznych. Taka współpraca okazuje się pomocna zarówno dla prawidłowej weryfikacji przyczyn zaburzeń, jak i pozwala na przyśpieszenie tego procesu. 


\section{Wnioski}

W opisywanym studium przypadku proces diagnostyczny początkowo doprowadził do postawienia rozpoznania stwardnienia zanikowego bocznego u badanego mężczyzny. Nie przeprowadzono jednak diagnostyki różnicowej $\mathrm{w}$ kierunku możliwego psychosomatycznego podłoża zaburzeń. Dopiero późniejsze postępowanie z zastosowaniem metod badania psychologicznego, psychiatrycznego, jak i obserwacji klinicznej doprowadziło do ustalenia rozpoznania zaburzeń konwersyjnych. Opisywany przypadek świadczy o tym, że przeprowadzenie pierwszej konsultacji psychiatrycznej i psychologicznej dopiero po trzech latach od wystąpienia objawów neurologicznych stanowi trudne do uzasadnienia zaniechanie. Warto zauważyć, że nawet $\mathrm{w}$ przypadku braku wątpliwości odnośnie somatycznego charakteru objawów, wystąpienie wyraźnej reakcji emocjonalnej na rozpoznanie poważnej choroby jest wskazaniem do wykonania konsultacji przez psychiatrę lub psychologa. Przedłużający się proces diagnostyczny - bez udziału specjalistów od zdrowia psychicznego - wpłynął negatywnie na stan psychiczny badanego oraz cały dalszy proces jego leczenia. Obserwowano u niego pogorszenie nastroju oraz znaczny spadek zaufania do personelu medycznego i niechęć do leczenia. Skutkowało to gorszą współpracą $\mathrm{w}$ procesie terapeutycznym, co ostatecznie negatywnie wpływało na uzyskiwanie poprawy objawowej oraz znacząco odroczyło odzyskiwanie sprawności przez mężczyznę. Bardzo istotnym aspektem jest również to, że wskutek rozpoznania u pacjenta śmiertelnej choroby neurologicznej mimo jej braku, doszło do pojawienia się u chorego traumy psychicznej.

Zastosowane $\mathrm{u}$ pacjenta leczenie farmakologiczne escitalopramem i mianseryną uzasadnione było występowaniem wyraźnych objawów depresji. Natomiast dane na temat efektywności takiego leczenia w odniesieniu do objawów konwersyjnych są skąpe. Wskazują one na możliwość korzystnego wpływu leków z grupy SSRI na złagodzenie nasilenia przewlekle występujących konwersyjnych objawów motorycznych [19]. Dane z badań klinicznych przemawiają za koniecznością prowadzenia u osób z zaburzeniami konwersyjnymi typu motorycznego skojarzonego leczenia farmakologicznego i psychoterapeutycznego [20,21]. Takie właśnie interwencje terapeutyczne zostały podjęte w przedstawionym przypadku, co przyniosło wyraźne obniżenie nasilenia objawów tak konwersyjnych, jak i depresyjnych.

\section{Conflict of interest}

The authors have declared no conflict of interest.

\section{References:}

1. Rubinowicz - Zasada M, Orczyk A, Orczyk M, Pasek J. Stwardnienie boczne zanikowe - choroba neuronu ruchowego. Prezentacja przypadku. Pediatria i Medycyna Rodzinna, 2015;11(1): 112-118.

2. Nguyen H.P, Van Broeckhoven C, Van der Zee J. ALS genes in the genomic era and their implications for FTD. Trends Genet., 2018; 34(6): 404-423.

3. Hübner I, Hübner J, Witek I, Kroczka S. Stwardnienie zanikowe boczne z objawami piramidowo - pozapiramidowymi oraz jako zespół paranowotworowy - opis dwóch przypadków. Polski Przegląd Neurologiczny, 2017;13(3):137-143..

4. Wijesekera LC, Leigh PN. Amyotrophic lateral sclerosis. Orphanet J Rare Dis., 2009;4:3.

5. Kędra E, Jaz AL. Jakość życia pacjentki wentylowanej mechanicznie w warunkach domowych z powodu stwardnienia bocznego zanikowego. Pielęgniarstwo i Zdrowie Publiczne, 2013;3 (2): 155-165.

6. Kubiszewska J, Kwieciński H. Stwardnienie boczne zanikowe. Sclerosis lateralis amyotrophica. Borgis - Postępy Nauk Medycznych, 2010;6: 440-448.

7. Adamek D, Tomik B. Stwardnienie Boczne Zanikowe. Wydanie I. Kraków; Wydawnictwo ZOZ Ośrodek UMEA Shinoda-Kuracejo: 2005.

8. Seligman M, Walker E, Rosenhan D. Psychopatologia. Poznań; Wydawnictwo Zysk i S-ka: 2003.

9. Pużyński S, Wciórka J. Klasyfikacja zaburzeń psychicznych i zaburzeń zachowaniaw ICD-10. Opisy kliniczne i wskazówki diagnostyczne. Kraków - Warszawa; Uniwersyteckie Wydawnictwo Medyczne Vesalius: 2000.

10. Stefańska A, Dziwota E, Stefański M, Nasiłowska-Barud A, Olajossy M. Modern faces of hysteria, or some of the dissociative disorders. Current Problems of Psychiatry, 2016; 17(3): 214-225.

11. Gałecki P, Święcicki Ł. Kryteria diagnostyczne z DSM-5. Desk Reference. Wrocław; Edra Urban \& Partner: 2015.

12. Hłodzik K, Dziwota E, Karakuła-Juchnowicz H, Olajossy M. Historia histerii i co dalej... Current Problems of Psychiatry 2016; 17(1): 31-37.

13. Dudzic- Koc A, Szałkowska A. Rodzinne i osobowościowe uwarunkowania zaburzeń konwersyjnych - studium przypadku. Pielęgniarstwo Polskie, 2015; 55: 99-104.

14. Araszkiewicz A. Zaburzenia dysocjacyjne. W: Pużyński S, Rybakowski J, Wciórka J red., Psychiatria. Tom 2: Psychiatria kliniczna. Wyd. II. Elsevier, Urban \& Partner: Wrocław, 2011: 453-466.

15. Pawełczyk T, Pawełczyk A, Rabe-Jabłońska J. Zanim rozpoznasz u pacjenta zaburzenie konwersyjne, zbadaj dokładnie jego stan somatyczny i neurologiczny. Opis przypadku. Psychiatria Polska, 2012; 46 (3): 483-492.

16. Koziorowska-Gawron E, Koszewicz M, Budrewicz S, Podemski R. Psychogenne zaburzenia chodu - opis trzech przypadków. Polski Przegląd Neurologiczny, 2014;10(4): 169-173.

17. Kubiak K. Zaburzenia dysocjacyjne (konwersyjne) u młodego mężczyzny z cechami osobowości histrionicznej: opis przy padku. Postępy Psychiatrii i Neurologii, 2000; 9, suplement 3 (11) : 103-107.

18. Stone J, Carson A. Neurologiczne objawy czynnościowe: diagnostyka i postępowanie. Neurologia po Dyplomie 2012; 7(2): 35-47

19. Voon V, Lang AE. Antidepressant treatment outcomes of psychogenic movement disorder. J Clin Psychiatry, 2005; 66 (12): 1529-1534

20. LaFrance WC Jr, Baird GL, Barry JJ, Blum AS, Frank Webb A, 
Keitner GI, Machan JT, Miller I, Szaflarski JP. NES Treatment Trial (NEST-T) Consortium. Multicenter pilot treatment trial for psychogenic nonepileptic seizures: a randomized clinical trial. JAMA Psychiatry, 2014; 71(9): 997-1005.

21. Bravo TP, Hoffman-Snyder CR, Wellik KE, Martin KA, Hoerth MT, Demaerschalk BM, Wingerchuk DM. The effect of selective serotonin reuptake inhibitors on the frequency of psychogenic nonepileptic seizures: a critically appraised topic. Neurologist. 2013; 19 (1): 30-33.

Infromacja na temat źródeł finansowania pracy:

Praca powstała w ramach działalności statutowej Katedry Psychiatrii, Collegium Medicum w Bydgoszczy, Uniwersytet Mikołaja Kopernika w Toruniu.

\section{Information regarding funding sources of the research} work:

The research work was funded by the basic operating funds of the Department of Psychiatry, Collegium Medicum in Bydgoszcz, Nicolaus Copernicus University in Toruń.

\section{Corresponding author:}

Sara Tomczak

Ist Department of Psychiatry, University Hospital No. 1 named after dr. A. Jurasz in Bydgoszcz. e-mail: sartompl@gmail.com

Otrzymano: 20.02.2019

Zrecenzowano:21.03.2019

Przyjęto do druku: 14.04.2019 